\title{
The effects of fat-free vs. fat-containing chocolate milk ingestion on muscular strength in female collegiate softball players
}

\author{
Bill Campbell ${ }^{1 *}$, Ashley Forsyth ${ }^{1}$, Bre Myers ${ }^{1}$, Brittany Parker ${ }^{1}$, Brittany Gomez ${ }^{1}$, Ava Elkins ${ }^{1}$, Colin Wilborn², \\ Paul La Bounty ${ }^{3}$, Brandon Marcello ${ }^{4}$
}

From International Society of Sports Nutrition: 9th Annual ISSN Conference and Expo

Clearwater, FL, USA. 22-23 June 2012

\section{Background}

Ingesting a post-workout beverage containing carbohydrate and high quality protein has been shown to favorably improve body composition and exercise performance. Chocolate milk supplies both carbohydrate and high quality proteins (casein and whey). For this reason, chocolate milk has become an increasingly popular sports nutrition beverage. To date, no one has investigated the differences between fat-free and fat-containing chocolate milk on strength performance in collegiate athletes. The purpose of this study, therefore, was to determine the effects of ingesting two forms of chocolate milk (fat free vs. fat containing) immediately after resistance exercise over an 8-week period to determine its effects on muscular strength.

\section{Methods}

In a double-blinded manner, 16 female collegiate softball players $(18.4 \pm 0.6 \mathrm{yrs} ; 167.1 \pm 4.4 \mathrm{~cm} ; 69.5 \pm 9.4 \mathrm{~kg})$ were randomized according to strength \& bodyweight to ingest a fat free $(300 \mathrm{kcals}, 58 \mathrm{~g}$ carbohydrate, $16 \mathrm{~g}$ protein, $0 \mathrm{~g}$ fat) or a fat-containing (380 kcals, $58 \mathrm{~g}$ carbohydrate, $16 \mathrm{~g}$ protein, $10 \mathrm{~g}$ fat) chocolate milk beverage. The chocolate milk was ingested in a 16 -ounce bottle \& occurred immediately following all periodized resistance exercise training sessions for a duration of 8-weeks. Dependent variables included 1RM Bench Press and 1RM Leg Press which were assessed at baseline \& following 8-weeks of a periodized resistance training program. Dependent variables were assessed as changes (delta scores) from pre- to post-testing in each group via an independent samples t-test using IBM SPSS Statistics (v19).

\section{Results}

1RM Bench Press at baseline and post-testing for the fat-free milk group was $87.5 \pm 18.7$ and $98.1 \pm 22.8 \mathrm{lbs}$ (an average improvement of $10.6 \pm 8.6$ pounds). For the fat-containing milk group, 1RM Bench Press at baseline and post-testing was 77.5 \pm 11.0 and $90.6 \pm 14 \mathrm{lbs}$ (an average improvement of $13.1 \pm 6.5$ pounds). There were no significant differences in changes from baseline to post-testing between the two groups $(\mathrm{p}=0.524)$. 1RM Leg Press at baseline and post-testing for the fat-free milk group was $285 \pm 68.9$ and $316.9 \pm 94.5$ lbs (an average improvement of $31.9 \pm 28.3$ pounds). For the fat-containing milk group, 1RM Leg Press at baseline and post-testing was $277.5 \pm 51.3$ and $303.1 \pm 51.3 \mathrm{lbs}$ (an average improvement of $25.6 \pm 10.5$ pounds). There were no significant differences in changes from baseline to post-testing between the two groups $(\mathrm{p}=0.567)$.

\section{Conclusions}

Based on these data, the ingestion of either fat-free chocolate milk or fat-containing chocolate milk will have similar effects in relation to upper and lower body strength changes when ingested immediately following resistance exercise over an 8 -week period in collegiate softball players.

* Correspondence: bcampbell@usf.edu

'University of South Florida, Tampa, Florida, USA

Full list of author information is available at the end of the article 


\section{Author details}

${ }^{1}$ University of South Florida, Tampa, Florida, USA. ${ }^{2}$ Mary Hardin-Baylor

University, Belton, TX, USA. ${ }^{3}$ Baylor University, Waco, Texas, USA. ${ }^{4}$ Stanford

University, Stanford, California, USA.

Published: 19 November 2012

doi:10.1186/1550-2783-9-S1-P3

Cite this article as: Campbell et al:: The effects of fat-free vs. fat-

containing chocolate milk ingestion on muscular strength in female collegiate softball players. Journal of the International Society of Sports

Nutrition 2012 9(Suppl 1):P3.

Submit your next manuscript to BioMed Central and take full advantage of:

- Convenient online submission

- Thorough peer review

- No space constraints or color figure charges

- Immediate publication on acceptance

- Inclusion in PubMed, CAS, Scopus and Google Scholar

- Research which is freely available for redistribution

Submit your manuscript at www.biomedcentral.com/submit 